\title{
NajCzęŚciej SPOTYKane KLAUzule abuzYWNe W UMOWACH LICENCYJNYCH NA KORZYSTANIE Z PROGRAMÓW KOMPUTEROWYCH
}

\section{Uwagi wstępne}

Występujące we współczesnym świecie procesy komputeryzacji i informatyzacji prowadzą do wykorzystywania programów komputerowych w życiu codziennym na coraz szerszą skalę. Z tym zjawiskiem związane jest zawieranie wielkiej ilości umów licencyjnych na korzystanie z programów komputerowych. Instalując, a czasem nawet już otwierając opakowanie programu, każdego dnia rzesze osób zawierają takie umowy. Wśród nich są również konsumenci. Pomimo faktu, iż tak wielu konsumentów zawiera tego typu umowy, na próżno szukać postanowień pochodzących z nich $\mathrm{w}$ rejestrze klauzul niedozwolonych, rzadko albo wcale nie są spotykane postępowania indywidualnie stwierdzające abuzywność klauzuli pochodzącej z takiej umowy. Niestety nie jest to równoznaczne $\mathrm{z}$ brakiem tego typu postanowień $\mathrm{w}$ omawianych umowach. W rzeczywistości można $\mathrm{w}$ nich spotkać klauzule dotyczące zawierania umów licencyjnych, sporządzania kopii zapasowej, zbierania danych, ograniczających odpowiedzialność czy też przeniesienia licencji lub programu na inną osobę lub komputer, które mogą okazać się krzywdzące dla konsumentów. Wobec powyższego, celem niniejszego artykułu jest, poprzez dokonanie analizy typowych klauzul występujących w umo-

* Mgr, absolwentka Wydziału Prawa i Administracji Uniwersytetu Śląskiego w Katowicach; 
wach licencyjnych na korzystanie z programów komputerowych oraz w oparciu o zagadnienia teoretyczne dotyczące programów komputerowych, umów licencyjnych i klauzul abuzywnych, wykazanie, iż tego typu umowy bardzo często zawierają niedozwolone postanowienia umowne, a także wskazanie najczęstszych zagrożeń, z jakimi stykają się konsumenci zawierający te umowy.

\section{Program komputerowy}

Podejmując analizę niedozwolonych postanowień umownych w licencjach na korzystanie z programów komputerowych, na wstępie należy przybliżyć trzy podstawowe pojęcia, jakimi są: program komputerowy, umowa licencyjna oraz klauzule abuzywne.

W Unii Europejskiej ochronę programów komputerowych reguluje Dyrektywa Parlamentu Europejskiego i Rady 2009/24/WE z dnia 23 kwietnia 2009 r. ${ }^{1}$. W polskim porządku prawnym natomiast, kwestii ochrony programów komputerowych dotyczy obecnie rozdział 7 ustawy z dnia 4 lutego 1994 r. o prawie autorskim i prawach pokrewnych ${ }^{2}$. Ze względu na postępujący rozwój technologiczny, zarówno w Dyrektywie 2009/24, jak i w polskiej ustawie nie występuje definicja pojęcia programu komputerowego, która mogłaby ulec szybkiej dezaktualizacji ${ }^{3}$.

Dyrektywa 2009/24 i ustawa polska wskazuja, iż programy komputerowe podlegają ochronie jak dzieła literackie. Aby program mógł być traktowany jako utwór, musi spełniać przesłanki stawiane przez art. 1 ust. 1 PrAut: być wytworzony przez człowieka, być ustalony (zakomunikowany), charakteryzować się jednością, spełniać przesłanki twórczości, czyli wytworu subiektywnie nowego oraz indywidualności ${ }^{4}$. Za traktowaniem programów jak dzieła literackie przemawia ich natura - są tworzone z pomocą znaków, jako pewnego rodzaju kod. Jednakże postuluje się, aby

${ }^{1}$ Dyrektywa Parlamentu Europejskiego i Rady 2009/24/WE z dnia 23 kwietnia 2009 r. w sprawie ochrony prawnej programów komputerowych, Dz. Urz. UE L Nr 111, poz. 16, dalej jako: Dyrektywa 2009/24.

${ }_{2}^{2}$ Ustawa z dnia 4 lutego 1994 r. o prawie autorskim i prawach pokrewnych, Dz.U. z 2006, nr 90, poz. 631 ze zm.., dalej jako: PrAut.

${ }^{3}$ Z. Okoń, [w:] P. Podrecki (red.), Prawo Internetu, Warszawa 2007, s. 433;

${ }^{4}$ J. Barta, R. Markiewicz, Prawo autorskie, Warszawa 2010, s. 26, 30-31; 
przepisy dotyczące dzieł literackich stosować w stosunku do programów jedynie pomocniczo, ze względu na pewne charakterystyczne regulacje dotyczące programów komputerowych ${ }^{5}$, takie jak zakaz dekompilacji, czyli odtwarzanie kodu źródłowego, umożliwiające poznanie jego treści ${ }^{6}$ (co jest istotą korzystania z utworów literackich) czy też zakaz modyfikacji, obejmującej wszelkie zmiany wprowadzane do kodu źródłowego, w tym także w zakresie opracowania, o którym mówi art. 2 ust. 1 PrAut ${ }^{7}$. Również Naczelny Sąd Administracyjny wskazał, iż programy komputerowe nie są kategorią utworów literackich, stwierdzając, iż są one dziełami rodzajowo odmiennymi ${ }^{8}$.

Zgodnie z art. 74 ust. 2 PrAut ochrona programów obejmuje wszystkie formy jego wyrażenia, niezależnie od tego czy występuje w postaci jedynie sporządzonych notatek, kodu źródłowego czy też dokonano już przetłumaczenia go na język wynikowy ${ }^{9}$. Ochrona obejmuje także program niedokończony oraz zawierający wady ${ }^{10}$. Z ochrony wynikającej z prawa autorskiego korzystają $\mathrm{zw}$. elementy tekstowe programu, czyli konkretny ciąg instrukcji1 ${ }^{11}$.

Inaczej niż w przypadku pozostałych utworów została uregulowana kwestia dozwolonego użytku programów komputerowych. Przepis art. 75 ust. 2 PrAut wymienia trzy obszary, w których nie jest wymagane zezwolenie uprawnionego: możliwość sporządzenia kopii zapasowej programu, gdy jest to niezbędne do korzystania z programu, uprawnienie osoby, która ma prawo do korzystania z programu, do obserwowania, badania i testowania funkcjonowania programu komputerowego, jeżeli ma to na celu poznanie idei i zasad tegoż programu oraz dozwolona w ściśle określonych wypadkach dekompilacja. Ponadto, art. 75 ust. 1 PrAut w braku odmiennych postanowień umownych, upoważnia podmiot, który wszedł w posiadanie programu komputerowego w sposób legalny do zwielokrotniania programu w całości lub części, tłumaczenia, przystoso-

5 Ibidem, s. 183;

${ }^{6}$ Ibidem, s. 186;

7 Z. Okoń, [w:] P. Podrecki (red.), Prawo Internetu, Warszawa 2004, s. 382;

${ }^{8}$ Wyrok NSA z dnia 20 września 2012 r., II FSK 245/11, LEX nr 1225389;

9 J. Barta, R. Markiewicz, [w:] J. Barta (red.), System Prawa Prywatnego, t. 13, Warszawa 2007, s. 861;

${ }_{10}$ M. Byrska, Program komputerowy w nowym prawie autorskim, „Państwo i Prawo" 1994, nr 11, s. 45-58;

${ }^{11}$ J. Barta, R. Markiewicz, [w:] J. Barta (red.), System..., s. 860; 
wywania i zmieniania go, o ile jest to niezbędne do korzystania z programu zgodnie $\mathrm{z}$ jego przeznaczeniem.

\section{Umowa licencyjna}

Definicja licencji zawarta została w art. 41 ust. 2 PrAut. Jest to umowa o korzystanie z utworu (rozumiane jako eksploatację praw autorskich, znajdujących się w strefie wyłączności uprawnionego ${ }^{12}$ ), na podstawie której twórca, bądź inny uprawniony podmiot ${ }^{13}$, nazywany licencjodawca, zgodnie z własną wolą i interesem ekonomicznym, zezwala na korzystanie z utworu, na ściśle określonych polach eksploatacji, innemu podmiotowi ${ }^{14}$, zwanemu licencjobiorcą. Jej następstwem nie jest skuteczne wobec wszystkich przeniesienie prawa autorskiego, lecz jedynie powstanie względnego uprawnienia licencjobiorcy ${ }^{15}$.

Licencje można podzielić zgodnie z art. 67 PrAut, na wyłączne, gwarantujące licencjobiorcy, że nikomu innemu nie zostanie udzielona licencja w zakresie tych samych pól eksploatacyjnych ${ }^{16}$, pod rygorem nieważności zawierane na piśmie oraz niewyłączne, które nie stoją na przeszkodzie udzielenia innym osobom licencji na tych samych polach eksploatacji, a także korzystania z utworu przez samego twórcę ${ }^{17}$. Występuje również podział na licencje pełne (licencjobiorca jest uprawniony do korzystania z utworu na wszystkich polach eksploatacyjnych, znanych w chwili zawierania umowy) i niepełne (umożliwiają korzystanie jedynie na niektórych polach) ${ }^{18}$, właściwe (udziela ich podmiot, któremu przysługują autorskie s. 474.

12 M. Kępińki, [w:] J. Barta (red.), System Prawa Prywatnego, t. 13, Warszawa 2008,

${ }^{13}$ J. Barta, R. Markiewicz, [w:] J. Barta, R. Markiewicz (red.), Prawo autorskie i prawa pokrewne. Komentarz, Warszawa 2011, s. 416;

${ }^{14}$ P. Ślęzak, Umowy w zakresie wspótczesnych sztuk wizualnych, Warszawa 2012, s. 181;

15 M. Czajkowska-Dąbrowska, Licencja nie przenosi prawa autorskiego, „Przegląd Prawa Handlowego" 1995, nr 7, s. 34-35;

${ }^{16}$ J. Barta, R. Markiewicz, [w:] J. Barta, R. Markiewicz (red.), Ustawa o prawie autorskim i prawach pokrewnych. Komentarz, LEX 2011, wersja elektroniczna, https://sip.lex.pl/\#/kome ntarz/587283695/109103?tocHit=1\&cm=REST.

17 P. Ślęzak, Umowy..., s. 191;

${ }^{18}$ K. Grzybczyk, Prawo właściwe dla autorskoprawnej umowy licencyjnej, Warszawa 2010, s. 36; 
prawa majątkowe) i sublicencje (udziela ich licencjobiorca) ${ }^{19}$, a także na zawierane na czas określony (po upływie pięcioletniego terminu licencję uważa się za udzieloną na czas nieoznaczony ${ }^{20}$ ), na czas nieokreślony oraz takie, w których nie określono czasu, na jaki zostały zawarte - $\mathrm{w}$ takim przypadku zgodnie z art. 66 ust. 1 PrAut, licencja uprawnia do korzystania z programu w okresie 5 lat i po upływie tego czasu wygasa.

Można również wyróżnić wiele rodzajów umów licencyjnych charakterystycznych dla programów komputerowych. Wśród nich warto wspomnieć o licencjach open source, polegających na udostępnianiu użytkownikom kodu źródłowego programu, w którym mogą dokonywać zmian, a także rozpowszechniać zmodyfikowane wersje na takiej samej licencji ${ }^{21}$. Występują także licencje typu shareware, na podstawie których program udostępniany jest na określony czas użytkownikowi do testowania, po czym musi zdecydować on, czy go nabędzie ${ }^{22}$, licencje typu adware, zazwyczaj darmowe, gdzie w trakcie instalacji lub użytkowania programu wyświetlane są reklamy ${ }^{23}$, czy też typu freeware, na podstawie których program udostępniany jest bezpłatnie i możliwe jest jego zwielokrotnianie ${ }^{24}$.

W przypadku programów komputerowych, licencjodawcą najczęściej nie będzie sam twórca, lecz wydawca programu - pracodawca twórcy lub współtwórców, zaś licencjobiorcami będą użytkownicy końcowi - osoby fizyczne lub prawne. W umowach licencyjnych konieczne jest określenie przedmiotu umowy i wyraźne wymienienie pól eksploatacyjnych, których dotyczy ${ }^{25}$. W omawianych licencjach, jako pola eksploatacyjne podaje się najczęściej uprawnienie wprowadzenia do pamięci komputera oraz sporządzania kopii zapasowej. Do elementów przedmiotowo istotnych umowy licencyjnej należy zaliczyć samo udzielenie uprawnienia do korzystania z utworu.

${ }^{19}$ M. Kępiński, [w:] J. Barta (red.), System..., s. 474;

${ }^{20}$ Wyrok SN z dnia15 października 2004 r., II CK 51/04, LEX nr 137579;

${ }^{21}$ P. Ślęzak, Umowy..., s. 196;

${ }^{22}$ J. Marcinkowska, Dozwolony użytek w prawie autorskim. Podstawowe zagadnienia, „Zeszyty Naukowe Uniwersytetu Jagiellońskiego” 2004, z. 2, s. 289-296;

${ }^{23}$ A. Suchorzewska, Ochrona prawna systemów informatycznych wobec zagrożeń cyberterroryzmem, Oficyna 2010, wersja elektroniczna;

24 J. Marcinkowska, Dozwolony..., s. 289-296;

${ }^{25}$ Wyrok SN z dnia 23 września 2004 r., III CK 400/2003, LEX nr 174201; 


\section{Klauzule abuzywne}

Na szczeblu Unii Europejskiej kontrolę postanowień umownych i interpretację wzorców reguluje Dyrektywa Rady 93/13/EWG z dnia 5 kwietnia 1993 r. ${ }^{26}$. Zakres podmiotowy Dyrektywa 93/13 zakreśla w art. 2 (b), wskazując, iż dotyczy ona każdej osoby fizycznej, działającej w celach niezwiązanych ze swoim zajęciem, przedsiębiorstwem lub zawodem w umowach objętych Dyrektywą 93/13. Dotyczy ona więc umów konsumenckich.

Dyrektywa 93/13 w art. 3 definiuje nieuczciwe warunki umowy, jako nienegocjowane indywidualnie oraz stojące w sprzeczności z wymogami dobrej wiary, a także ze szkodą dla konsumenta, prowadzące do znaczącej nierównowagi praw i obowiązków stron. Dyrektywa 93/13 przewiduje dwie formy kontroli, po pierwsze formalna, która związana jest $\mathrm{z}$ badaniem transparentności wzorca, odnoszącej się do umowy jako fizycznego przedmiotu, jej dostępności czy też czytelności, a także czy jest sformułowana w sposób zrozumiały i prosty ${ }^{27}$. Po drugie, występuje kontrola materialna, która polega na badania postanowień konkretnej umowy pod kątem kryteriów zawartych $\mathrm{w}$ art. 3, przy uwzględnieniu kontekstu jej zawarcia ${ }^{28}$. W przypadku kontroli indywidualnej, art. 6 wskazuje, że nieuczciwe warunki umowy nie będą dla konsumenta wiążące, natomiast umowa, o ile będzie to możliwe po wyłączeniu owych warunków, w pozostałej części pozostanie nadal obowiązująca. Natomiast w wypadku kontroli abstrakcyjnej, zgodnie z art. 7, poszczególne państwa winny stworzyć odpowiedni system, który określi sankcje ${ }^{29}$.

W prawie polskim pojęcia niedozwolonych postanowień umownych dotyczy przede wszystkim art. 385¹ ustawy z dnia 23 kwietnia 1964 r. Kodeks cywilny ${ }^{30}$. Klauzule, aby zostać uznane za abuzywne, po pierwsze muszą występować w umowie konsumenckiej, co wyłącza kontrolę innych dwustronnych czynności prawnych oraz wszelkich czynności jedno-

${ }^{26}$ Dyrektywa Rady 93/13/EWG z dnia 5 kwietnia 1993 r. w sprawie nieuczciwych warunków w umowach konsumenckich, Dz. Urz. UE Nr 95, poz. 29, dalej jako: Dyrektywa 93/13

27 E. Łętowska, Europejskie prawo umów konsumenckich, Warszawa 2004, s. 263;

${ }^{28}$ Ibidem, s. 264;

${ }^{29}$ Ibidem, s. 275;

${ }^{30}$ Ustawa z dnia23 kwietnia 1964 r. - Kodeks cywilny, Dz.U. nr 16 poz. 93 ze zm.; 
stronnych $^{31}$. Po drugie nie są z konsumentem uzgodnione indywidualnie, przez co należy rozumieć, iż brak jest realnego wpływu na ukształtowanie danego postanowienia umownego. Po trzecie, postanowienia te w sposób sprzeczny z dobrymi obyczajami muszą kształtować prawa i obowiązki konsumenta, co winno być interpretowane w zgodzie z wykładnią Dyrektywy 93/13 ${ }^{32}$, która w art. 3 ust. 1 odwołuje się do sprzeczności z wymogami dobrej wiary oraz wywoływania znaczącej nierównowagi między stronami umowy. Postanowienia te muszą także rażąco naruszać interesy konsumenta, rozumiane w sensie materialnym, przy których określaniu należy brać pod uwagę kryteria zarówno obiektywne (np. wysokość poniesionych strat), jak i subiektywne, takie jak wiek konsumenta ${ }^{33}$. Rażące naruszenie interesu konsumenta może też dotyczyć innych aspektów aniżeli ekonomiczne, jak np. naruszenia prywatności konsumenta ${ }^{34}$. Ochrona ta jednakże nie znajduje zastosowania w przypadku postanowień określających główne świadczenie stron, lecz jedynie, jeżeli zostały sformułowane w sposób jednoznaczny.

Przewidziane są dwa rodzaje kontroli: incydentalna oraz abstrakcyjna. Kontrola incydentalna dokonywana jest przez sąd, poprzez ocenę danego postanowienia przy pomocy klauzuli generalnej zawartej $\mathrm{w}$ art. $385^{1} \S 1$ k.c. lub listy klauzul abuzywnych wymienionych $\mathrm{w}$ art. $385^{3}$ k.c. ${ }^{35}$, których stosowanie nie jest bezwzględnie zakazane, lecz dopiero przy użyciu klauzuli interpretacyjnej „w razie wątpliwości” mogą zostać uznane za postanowienia abuzywne ${ }^{36}$. Kontrola ta, może mieć miejsce w wypadku, gdy konsument podnosi zarzut bezskuteczności postanowienia w ramach już toczącego się postępowania ${ }^{37}$ albo poprzez wszczęcie przez konsumenta postępowania, którego celem jest ustalenie bezskuteczności danej

${ }^{31}$ M. Skory, Klauzule abuzywne w polskim prawie ochrony konsumenta, Zakamycze 2005, s. 126 ;

${ }^{32}$ M. Pecyna, Kontrola wzorców umownych poza obrotem konsumenckim, Zakamycze 2003, s. 142 ;

${ }^{33}$ M. Bednarek, [w:] E. Łętowska (red.), System Prawa Prywatnego, Tom 5, Prawo zobowiazań - część ogólna, Warszawa 2006, s. 663;

${ }^{34}$ E. Łętowska, Prawo umów konsumenckich, Warszawa 2002, s. 341;

35 Ibidem, s. 335;

${ }^{36}$ M. Bednarek, [w:] E. Łętowska (red.), System..., s. 668;

37 Jak wskazał Sąd Apelacyjny w Warszawie w wyroku z dnia 2 września 2010 r., I ACa 514/10, LEX nr 1120143 podczas rozpoznawania spraw między konsumentem a przedsiębiorca, sąd może nawet z urzędu dokonać ustaleń dotyczących ochrony konsumenta przed klauzulami abuzywnymi, gdyż jest ona skuteczna ex lege; 
klauzuli $^{38}$. Orzeczenie sądu stwierdzające bezskuteczność konkretnego postanowienia umownego, będzie miało charakter deklaratoryjny ${ }^{39}$, wiązać zaś będzie jedynie strony danego postępowania, gdyż jego celem jest objęcie ochroną indywidualnego interesu konsumenta ${ }^{40}$. W następstwie kontroli incydentalnej sąd może stwierdzić bezskuteczność badanego postanowienia (nie zaś nieważność całej umowy), natomiast powstała w umowie luka po danym postanowieniu, powinna zostać uzupełniona odpowiednimi przepisami dyspozytywnymi ${ }^{41}$.

Jeżeli natomiast chodzi o kontrolę abstrakcyjna, obecnie zgodnie z art. 23b ustawy z dnia 16 lutego 2007 r. o ochronie konkurencji i konsumentów ${ }^{42}$, Prezes Urzędu Ochrony Konkurencji i Konsumentów wydaje decyzję o uznaniu postanowienia wzorca umowy za niedozwolone i zakazującą jego wykorzystywania, jeżeli stwierdzi naruszenie zakazu stosowania we wzorcach umów zawieranych z konsumentami niedozwolonych postanowień umownych, o których mowa w art. $385^{1} \S 1$ k.c. Warto zauważyć, iż zgodnie z art. 23d tejże ustawy, decyzja ta ma skutek wobec przedsiębiorcy, co do którego stwierdzono stosowanie niedozwolonego postanowienia umownego oraz wobec wszystkich konsumentów, którzy zawarli z nim umowę na podstawie wzorca wskazanego w decyzji.

\section{Klauzule dotyczące sposobu zawierania umów licencyjnych}

Omówiwszy podstawowe zagadnienia, można przejść do analizy poszczególnych rodzajów klauzul abuzywnych, które najczęściej są spotykane $\mathrm{w}$ umowach licencyjnych na korzystanie z programów komputerowych.

Po pierwsze można wyróżnić klauzule dotyczące zawierania umów. Wśród nich wyróżniamy tzw. licencję celofanową (shrink-wrap), web-wrap oraz click-wrap.

${ }^{38}$ M. Bednarek, [w:] E. Łętowska (red.), System..., s. 684;

${ }^{39}$ Ibidem, s. 687;

${ }^{40}$ Postanowienie SN z 25 października 2012, I CZ 135/12, LEX nr 1293690;

${ }^{41}$ E. Łętowska, Prawo umów konsumenckich, Warszawa 2002, s. 343;

${ }_{42}$ Ustawa w dnia16 lutego 2007 r. o ochronie konkurencji i konsumentów, tekst jednolity, Dz. U. z 2015 r., poz. 184. 


\section{a) Shrink-wrap}

Nazwa ta pochodzi od przezroczystego opakowania, przez które można zobaczyć umieszczoną na pudełku informację, iż jego rozerwanie jest jednoznaczne z zawarciem umowy licencyjnej ${ }^{43}$. Nie zawsze jednak pełny tekst umowy znajduje się na zewnątrz opakowania, zaś użytkownik chcąc poznać postanowienia umowy znajdujące się w pudełku lub na płycie, jest zmuszony otworzyć opakowanie, a czyniąc to zawiera umowę licencyjną, nie znając jej treści. Umowom takim często towarzyszy tzw. umowa wspierająca (back-up agreement), polegająca na dodatkowym wyrażaniu zgody na postanowienia umowy podczas instalacji oprogramowania, mająca stanowić gwarancję zapoznania się użytkownika z treścią umowy ${ }^{44}$. Wątpliwe wydaje się jej znaczenie, skoro do zawarcia umowy dochodzi już przy zerwaniu opakowania.

Problemem umów celofanowych wielokrotnie zajmowały się sądy amerykańskie, początkowo uznając je za nieważne, ze względu na brak możliwości zapoznania się nabywcy z postanowieniami umowy przed otwarciem opakowania, równoznacznym z zawarciem umowy. Jednakże w przełomowym, kontrowersyjnym wyroku w sprawie ProCD, Int. $v$. Zeidenberg z 20 czerwca $1996 \mathrm{r}^{45}$, uznano taką umowę za ważna, argumentując, iż w czasie instalacji, nabywca może zrezygnować z umowy, przeczytawszy postanowienia licencji na ekranie komputera, a potem zwrócić zakupiony egzemplarz ${ }^{46}$. Ponad to wskazano, iż drukowanie całej umowy licencyjnej na zewnątrz opakowania jest niepraktyczne ${ }^{47}$.

Mimo to $\mathrm{w}$ literaturze nadal występuje pogląd ${ }^{48}$, iż w wypadku, gdy nie jest możliwe zapoznanie się przez nabywcę z postanowieniami licencji przed rozpakowaniem egzemplarza, należy odmówić doniosłości prawnej zastrzeżeniu, że otwarcie oznacza zgodę na postanowienia znajdującej

${ }^{43}$ P. Wasilewski, Umowy licencyjne open content jako przykład umów web-wrap, „CBKE Biuletyn" 2007, nr 3, s. 7;

${ }_{44}$ A. Krochmal-Węgrzyn, Umowa licencyjna a Internet, „Przegląd Prawa Handlowego” 2004, nr 6, s. 47;

${ }^{45}$ Wyrok United States Court of Appeals for the Seventh Circuit z dnia 20 czerwca 1996 r., ProCD, Inc. v. Zeidenberg, 86 F.3d 1447, https://www.courtlistener.com/opinion/720542/procd-inc-v-zeidenberg/?

${ }^{46}$ D. Kot, Elektroniczny obrót utworem w świetle prawa autorskiego, „Prace Instytutu Własności Intelektualnej Uniwersytetu Jagiellońskiego" 2006, z. 94, s.150-151;

47 A. Krochmal-Węgrzyn, Umowa..., s. 48;

${ }^{48}$ R. Sikorski, Licencje na korzystanie z elektronicznych baz danych, Warszawa 2006, s. 107; 
się w środku umowy, gdyż strona nie może złożyć oświadczenia woli co do postanowień, których treści nie zna.

Wydaje się, iż w konkretnych przypadkach postanowienie umowne, na podstawie którego otwarcie opakowania jest równoznaczne z zawarciem umowy licencyjnej, może być krzywdzące dla licencjobiorcy. Umowa licencyjna może bowiem zawierać inne postanowienia, na które nie chce on wyrazić zgody, a ze względu na które umowy takiej nigdy by nie zawarł. Z powodu jednak otwarcia opakowania zostaje związany postanowieniami umownymi, których treści w momencie zawierania umowy nie znał.

Ponadto, wątpliwym wydaje się argumentacja, iż egzemplarz programu zawsze można zwrócić, jeżeli licencjobiorca nie zgadza się na postanowienia umowy. Należy bowiem zauważyć, że licencjobiorca zawiera zazwyczaj dwie umowy: sprzedaży, w momencie zakupu egzemplarza $\mathrm{w}$ sklepie oraz licencyjna, w momencie otwarcia opakowania. Zwrot egzemplarza może z jednej strony nie być równoznaczny z odstąpieniem od umowy licencyjnej, z drugiej zaś - licencjobiorca może nie mieć możliwości zwrotu zakupionego, otwartego egzemplarza programu, a postanowienia licencji nie mogą zmusić sprzedawcy do jego przyjęcia.

\section{b) Web-wrap}

Inaczej zawierane są umowy licencyjne typu web-wrap (inaczej nazywane brose-wrap): przy pomocy strony internetowej, przez dokonanie przez licencjobiorcę określonej, wskazanej w umowie czynności. Tekst umowy powinien być dostępny bezpośrednio na witrynie internetowej albo $\mathrm{w}$ formie odesłania, w sposób umożliwiający zapoznanie się z nim przez każdego potencjalnego licencjobiorcę ${ }^{49}$. Charakterystyczne jest, iż umowy te zawieranie są wyłącznie w trybie on-line, a co więcej - przed zapłata, czego nie spotyka się w dwóch pozostałych typach umów ${ }^{50}$.

Ponieważ w przypadku tego rodzaju zawierania umów licencyjnych, nie występuje wyraźne zaznaczenie wyrażenia zgody na postanowienia umowy, na przykład poprzez kliknięcie przycisku „zgadzam się" pod tekstem treści umowy, dostęp do warunków umowy winien być łatwy

\footnotetext{
${ }^{49}$ P. Wasilewski, Umowy..., s. 7;

50 A. Krochmal-Węgrzyn, Umowa..., s. 51;
} 
i odpowiedni (zwracały na to uwagę między innymi sądy amerykańskie ${ }^{51}$ ). W innym wypadku, licencjobiorca poprzez kliknięcie dla przykładu przycisku „pobierz”, mógłby w ogóle nie poznać postanowień umownych lub nawet nie uświadamiać sobie, iż już doszło do zawarcia umowy. Umowa taka natomiast mogłaby zawierać postanowienia, na które licencjobiorca nie wyraża zgody.

Jako przykład dobrze zastosowanej metody zawierania umowy typu web-wrap można wskazać sytuację, gdy w produktach wielokrotnie powtarzało się ostrzeżenie, że transakcja jest przedmiotem zasad i warunków sprzedaży, do którego załączony był wyraźny hiperlink, za pośrednictwem którego można było się z nimi zaznajomićs ${ }^{2}$.

\section{c) Click-wrap}

Kolejną jest licencja z języka angielskiego zwana click-wrap. Licencjobiorca zapoznaje się z postanowieniami licencji, w niektórych przypadkach wnosi opłatę licencyjna, a także, od czego pochodzi angielska nazwa tego typu licencji, musi zaakceptować warunki licencji poprzez kliknięcie pola uzewnętrzniającego zgodę na wskazane warunki, takie jak np. „Zgadzam się", "Tak”, „Yes", co jednocześnie oznacza zawarcie takiej umo$w^{53}$. Aby istniała pewność, iż użytkownik zapoznał się z postanowieniami umowy oraz świadomie wyraża zgodę na jej postanowienia, obecnie występują dwa przyciski: jeden wyrażający zgodę, drugi wyrażający jej brak. Automatycznie zaznaczony jest przycisk oznaczający brak zgody, co uniemożliwia przejście do następnego etapu instalacji. Celem takiego działania jest spowodowanie świadomego wyrażenia zgody na zawarcie umowy licencyjnej określonej treści. Wydaje się, iż ten sposób zawarcia umowy licencyjnej jest najbardziej klarowny i bezpieczny dla potencjalnego nabywcy, gdyż udostępniony jest w trakcie instalacji pełny tekst posta-

${ }^{51}$ Orzeczenie United States District Court for the Central District of California z dnia 27 marca 2000 r., Ticketmaster Corp, et al. v. Tickets.co m, Inc., Case No. CV 99-7654 HLH (BQRx), www.internetlibrary.com/pdf/Ticketmaster-Tickets.com-CD-Ca-Mtn-Dismiss. pdf

52 Orzeczenie Appellate Cort of Illinois z dnia 12 sierpnia 2005 r., Hubbert v. Dell Corp., 835 N.E. 2d 113, Docket Number: 5-03-0643, www.internetlibrary.com/pdf/Hubbert-Dell. pdf

53 P.Ślęzak, Umowy w zakresie wspótczesnych sztuk wizualnych, LEX 2012, wersja elektroniczna: https://sip.lex.pl/\#/monografia/369245766/80?tocHit=1 
nowień umownych, do którego nie ma utrudnionego dostępu, po drugie zaś - do zawarcia umowy dochodzi zawsze po zaistnieniu możliwości zapoznania się z jej treścią a brak zaznajomienia się z postanowieniami umownymi przed kliknięciem pola akceptacji jest świadomą decyzją licencjobiorcy.

Poza typowymi umowami shrink-wrap, web-wrap oraz click-wrap istnieją też licencje łączące dwa lub trzy sposoby zawarcia umowy, w których jakiekolwiek ze wskazanych przez nie zachowań użytkownika może spowodować zawarcie umowy. W umowach można się spotkać z postanowieniami, iż za zawarcie umowy licencyjnej uważa się zarówno pobranie, oprogramowania, jego instalację, kliknięcie przycisku wyrażającego zgodę, używanie programu, a nawet niekiedy jakiekolwiek zachowanie wyrażające zgodę na zawarcie umowy. Tak nieprecyzyjne wskazanie momentu zawarcia umowy może okazać się niekorzystne dla użytkownika, gdyż bez zamiaru wyrażania zgody może dokonać nieświadomie takiej czynności, która będzie się zawierała w tym szerokim wyliczeniu. Wydaje się, iż w porównaniu do wyżej wymienionych, klauzule takie najczęściej mogę nosić znamiona abuzywności, gdyż nieświadomy konsument może zawrzeć umowę licencyjna, pomimo iż tego nie chce, dokonując jakąś zwykłą czynność związaną z programem, w której licencjodawca zapatruje momentu zawarcia umowy, nawet przed możliwością zapoznania się z jej treścią.

\section{Klauzule dotyczące kopii zapasowej}

Jak już wskazano, art. 75 ust. 2 pkt 1 PrAut przewiduje uprawnienie do utworzenia kopii zapasowej programu komputerowego. Wśród umów licencyjnych, po pierwsze istnieją umowy, w których możliwość utworzenia kopii zapasowych przez użytkownika zagwarantowana jest bez dodatkowych ograniczeń czy zastrzeżeń, także ilościowych, co oczywiście czyni najbardziej komfortową sytuację licencjobiorcy.

Po drugie, istnieją umowy zawierające ograniczenia co do celu utworzenia kopii zapasowej, stanowiące, iż może być ona utworzona tylko dla zastąpienia legalnie posiadanego egzemplarza, jeżeli zostanie on np. zniszczony lub utracony. Postanowienie takie stanowi jedynie potwierdzenie celu ustawowego, nie może być więc uważane za klauzulę abuzywną. 
Istnieją jednakże także umowy ograniczające w sposób ilościowy możliwość tworzenia kopii zapasowych, stanowiące zazwyczaj, że użytkownik może utworzyć tylko jedną kopię zapasową programu. W literaturze nie ma zgody, czy wyżej wskazany przepis uprawnia jedynie do utworzenia jednej kopii, czy może być ich więcej. W konkretnym przypadku jedna kopia zapasowa programu może jednak nie zapewnić bezpieczeństwa użytkownika. W takim wypadku postanowienie ograniczające ilość kopii do jednej okaże się krzywdząca dla konsumenta.

Ponadto można spotkać umowy, które w ogóle nie precyzuja, czy możliwe jest sporządzanie kopii zapasowej, jednakże wobec art. 75 ust. 2 PrAut należy przyjmować, iż sporządzenie takiej kopii jest dopuszczalne.

\section{Klauzule dotyczące zbierania danych}

W niektórych umowach, m.in. dotyczących programów antywirusowych, istnieją postanowienia o gromadzeniu informacji pochodzących z komputera użytkownika. Wskazuje się w nich dla przykładu, iż celem zbierania informacji jest ulepszenie oferowanych zabezpieczeń czy też poznanie nowych zagrożeń.

W wypadku programów antywirusowych, działanie takie wydaje się być uzasadnione, ponieważ bez niego odpada główna ich funkcja, zaś użytkownik winien uświadamiać sobie, iż istotą takich programów jest badanie pamięci komputera czy też odwiedzanych stron internetowych, aby możliwe było wyeliminowanie zagrożeń. Wydaje się jednak, iż w umowach winno występować zastrzeżenie, że "Oprogramowanie nie przetwarza żadnych danych pozwalających na identyfikację jednostki, nie łączy też przetwarzania danych z żadnymi informacjami osobowymi" ${ }^{54}$, co zapewnia anonimowość użytkownika i jego bezpieczeństwo, a złamanie takiego postanowienia naraża licencjodawcę na odpowiedzialność ex contractu. Ponadto, o możliwości zbierania danych użytkownik winien być poinformowany, aby mógł w pełni świadomie zdecydować o instalacji programu, a także o ewentualnym odinstalowaniu.

${ }^{54}$ Umowa licencyjna użytkownika końcowego firmy Kaspersky LAB, http://www.kaspersky.pl/download/licencje/eula_kaspersky_internet_security_2013.pdf; 
Występują też licencje, w których zbieranie danych ma na celu zweryfikowanie, czy inne oprogramowanie tego samego licencjodawcy, zainstalowane na komputerze licencjobiorcy jest oryginalne lub czy użytkownik nie korzysta $z$ innego oprogramowania, którego używanie równocześnie $\mathrm{z}$ przedmiotowym programem jest zgodnie z umową licencyjną niedozwolone. Wobec tego istnieje potrzeba porównania instrumentów ochrony praw autorskich licencjodawcy oraz możliwości naruszenia praw licencjobiorcy, takich jak np. prywatność. Badanie pamięci komputera jest jedną z niewielu możliwości, które w celu ochrony swoich praw technicznie może zastosować licencjodawca. Wobec tego można by przyjąć jego dopuszczalność, jednakże przy jednoczesnym zastrzeżeniu, że pozostałe pozyskane przez licencjodawcę dane, nie będą w żaden sposób przetwarzane, natomiast identyfikacja nastąpi jedynie poprzez powiązanie informacji z konkretnym kontem, nie. nastąpi natomiast jakakolwiek dalsza identyfikacja danych użytkownika. Nadto powinny być wyraźnie wymienione programy, które będą poszukiwane w pamięci komputera.

Wydaje się, iż klauzule dotyczące zbierania danych, nie ograniczone w sposób opisany powyżej, można uznać za klauzule niedozwolone. Silniejszy kontrahent zmusza w tym wypadku konsumenta do zgody na ujawnienie mu danych, które mogą dotyczyć jego sfery prywatnej, co można uznać za sprzeczne z dobrymi obyczajami, a ponadto nie jest pewne w jaki sposób zostaną wykorzystane i czy nie zostaną nikomu przekazane. Złe wykorzystanie tak uzyskanych danych przez licencjodawce może narazić konsumenta na poważne szkody, może się także okazać, iż znajdą się w posiadaniu osób, które nie powinny mieć do nich dostępu, a które mogą wykorzystać je sprzecznie $\mathrm{z}$ interesami konsumenta. $\mathrm{Z}$ tych też powodów można je uznać za godzące w sposób rażący w interesy konsumenta.

\section{Klauzule CPU}

Klauzule CPU (z j. angielskiego Central Processing Unit) dzielą się na uzależniające możliwość korzystania z programu komputerowego od określonych parametrów technicznych komputera, przede wszystkim poprzez zakaz używania programu na komputerze o wyższej mocy obliczeniowej bez zgody licencjodawcy oraz takie, które upoważniają licen- 
cjobiorcę do korzystania z programu jedynie na określonym sprzęcie komputerowym. Ten drugi rodzaj klauzul można podzielić na tzw. „miękkie” $\mathrm{i}$ „twarde" klauzule CPU ${ }^{55}$.

„Miękkie” klauzule CPU wskazują maksymalną liczbę komputerów, na których może zostać program zainstalowany, stanowiąc, że np. użytkownik może dokonać instalacji programu tylko na jednym czy dwóch komputerach. Klauzule te co do zasady nie wzbudzają kontrowersji i wydaje się, iż są dopuszczalne ${ }^{56}$. Głębiej jednakże zastanawiając się nad tym problemem, można powziąć wątpliwość, czy w niektórych sytuacjach nie naruszają one interesów konsumenta. Może bowiem nastąpić sytuacja, w której licencjobiorca, posiadający dwa komputery, używa dane oprogramowanie do nauki czy pracy (np. edytor tekstu), zaś w umowie występuje zastrzeżenie co do możliwości instalacji programu jedynie na jednym komputerze. Licencjobiorca taki musiałby dla siebie samego zawierać, zazwyczaj odpłatna, umowę licencyjną na każdy komputer z osobna, co być może byłoby podstawą do uznania takiej klauzuli za niedozwoloną.

Twarde klauzule CPU zakazują korzystania z programu na innym komputerze, poza konkretnym, oznaczonym co do tożsamości. Ich konsekwencją jest brak możliwości przeniesienia oprogramowania na inny komputer ${ }^{57}$.

W sytuacji, gdy licencjobiorca chce zainstalować oprogramowanie na nowym komputerze należącym do niego (np. gdy poprzedni sprzęt uległ zniszczeniu), wydaje się, iż taka klauzula może mieć charakter abuzywny. Nie zmieniają się bowiem strony umowy, nie dochodzi do przeniesienia licencji na innego użytkownika, zaś zakaz używania programu komputerowego przez tego samego licencjobiorcę, co jest istotą zawieranej umowy, z pewnością narusza interes konsumenta, czyniąc to ponadto w sposób rażący, gdyż uniemożliwia licencjobiorcy korzystanie z podstawowego uprawnienia wynikającego z umowy. Ponadto uwidacznia się tutaj nadużycie silniejszej pozycji profesjonalisty, można więc uznać taką klauzulę za sprzeczną z dobrymi obyczajami, również dlatego, iż licencjobiorca w takim wypadku musiałby zawrzeć nowa, odpłatną umowę licencyjna, która umożliwiałaby mu korzystanie z programu, które to uprawnienie już uprzednio uzyskał.

${ }_{55}$ B. Giesen, Umowa licencyjna w prawie autorskim. Struktura i charakter prawny, Warszawa 2013, s. 415.

56 Ibidem, s. 415.

57 Ibidem, s. 422. 


\section{Klauzule dotyczące przeniesienia licencji}

Niektóre z umów licencyjnych na korzystanie z programów komputerowych zawierają zgodę na przeniesienie przez pierwotnego użytkownika egzemplarza programu wraz z prawami i obowiązkami wynikającymi z licencji na innego użytkownika, jednakże często jednocześnie stawiając warunek wyrażenia zgody na postanowienia umowy przez nowego użytkownika, przekazania mu wszystkich kopii programu czy zakazując przekazania klucza oprogramowania bez samego programu. Postanowienia te służą zapewnieniu przestrzegania umowy przez nowego użytkownika oraz ochronie praw autorskich, nie szkodzą zaś w żaden sposób interesom konsumentów, nie można więc ich uznać za abuzywne.

Istnieją jednakże umowy zawierające bezwzględny zakaz przekazywania oprogramowania oraz przenoszenia licencji na inną osobę. Do realizacji tych klauzul dochodzi m.in. w sytuacji, gdy konieczna jest rejestracja oprogramowania za pomocą Internetu, czy też do oprogramowania załączony jest klucz jednorazowego wykorzystania.

W tej kwestii wypowiedział się Trybunał Sprawiedliwości Unii Europejskiej w wyroku z 3 lipca 2012 r. w sprawie Oracle vs. UsedSoft $t^{58}$, wskazując, iż pierwszą sprzedażą kopii programu w rozumieniu art. 4 ust. 2 Dyrektywy 2009/24 (stanowiącym, iż pierwsza sprzedaż na terytorium Unii Europejskiej kopii programu komputerowego przez uprawnionego lub za jego zgodą wyczerpuje prawo dystrybucji tej kopii na terytorium Unii) jest przekazanie użytkownikowi kopii programu komputerowego przez podmiot uprawniony, jeżeli dochodzi między nimi do zawarcia umowy licencyjnej. „Sprzedaż” należy bowiem rozumieć szeroko, jako każde wprowadzenie kopii programu do obrotu, jeżeli przyznaje prawo do korzystania z tej kopii programu na czas nieoznaczony, a w zamian zostaje jednorazowo za nią zapłacona cena. W innym wypadku nazwanie umowy licencją zamiast umową sprzedaży prowadziłoby do obejścia art. 4 ust. 2 Dyrektywy 2009/2459. Mając na względzie powyższe, Trybunał stwierdził, iż gdy dokonano odsprzedaży licencji na korzystanie z progra-

${ }^{58}$ Wyrok Trybunału Sprawiedliwości Unii Europejskiej z dnia 3 lipca 2012 r., C-128/11, http://curia.europa.eu/juris/document/document.jsf?text=\&docid=124564\&pageIndex=0\& doclang=PL\&mode=lst\&dir=\&occ=first\&part=1\&cid=489176

59 Opinia rzecznika generalnego Yves'a Bota przedstawiona w dniu 24 kwietnia 2012 r., pkt 59,"http://curia.europa.eu/juris/document/document.jsf?text=\&docid=121981\& pageIndex=0\&doclang=PL\&mode=1st\&dir $=\&$ occ $=$ first\&part $=1 \&$ cid $=489176$ 
mu wraz z odsprzedażą jego kopii, zarówno drugi nabywca oraz każdy kolejny mogą powoływać się na wyczerpanie prawa, czyli są uprawnionymi nabywcami kopii programu w świetle art. 5 ust. 1 Dyrektywy 2009/24. Wobec tego, należy uznać klauzule zakazujące przeniesienia kopii i licencji na innego użytkownika za abuzywne.

We wspomnianym wyroku Trybunał rozważył również sytuację, gdy umowa zabrania przeniesienia licencji, w przypadku nie posiadania przez użytkownika fizycznego egzemplarza programu. Trybunał wskazał, iż Dyrektywa 2009/24 chroni programy komputerowe w każdej formie (art. 1 ust. 2), przez co forma materialna i niematerialna programu są względem siebie równe i nie można różnicować możliwości ich przeniesienia. Ponadto, wskazał na ekonomiczne podobieństwo między sprzedażą programu poprzez pobranie z Internetu a formą tradycyjną - na płycie. Gdyby wyczerpanie prawa dotyczyło jedynie programów na nośnikach, podmiot praw autorskich mógłby kontrolować obrót kopią pobraną z Internetu, a przez to, żądać zapłaty za każdą dalszą sprzedaż kopii, pomimo otrzymania zapłaty od pierwszego nabywcy. Podsumowując, prawo do rozpowszechniania kopii programu komputerowego zostaje wyczerpane, również gdy kopia programu została pobrana z Internetu, a podmiot praw autorskich, przyznał, w zamian za zapłatę ceny, prawo do nieograniczonego w czasie korzystania z niej.

\section{Klauzule jurysdykcyjne}

Przepis art. $385^{3}$ pkt 23 k.c., stanowi, iż postanowienia umowne wyłączające jurysdykcję sądów polskich lub poddające sprawę pod rozstrzygnięcie sądu polubownego polskiego lub zagranicznego lub innego organu, a także narzucające rozpoznawanie sprawy przez sąd, który wedle ustawy nie jest miejscowo właściwy, w razie wątpliwości uważa się za niedozwolone. Wśród umów licencyjnych na korzystanie z programów komputerowych, zawieranych z licencjodawcami będącymi często podmiotami zagranicznymi, należy zwrócić uwagę, iż istnieją umowy, które przewidują jurysdykcję sądów zagranicznych lub innych zagranicznych instytucji, a jedynie $\mathrm{w}$ wąskiej grupie roszczeń zakładają możliwość dochodzenia ich przez konsumenta w sądzie właściwym, naruszając tym samym interes konsumenta. Klauzule wyłączające jurysdykcję sądów 
polskich, jeżeli ich właściwość wynika z przepisów prawa, wydaje się, iż należy uznać za abuzywne. Co do pozostałych klauzul, można przychylić do poglądu, mówiącego, iż należy przyjrzeć im się bliżej pod kątem interesu konsumenta, może się bowiem okazać, iż teoretycznie niedozwolone postanowienia będą bardziej korzystne dla konsumenta, gdy dla przykładu będą one poddawać sprawę pod jurysdykcję organu szczególnie powołanego do rozstrzygnięcia spraw określonego rodzaju, posiadającego konieczna, profesjonalną wiedzę z danej dziedziny czy też zapewniającego szybkie rozstrzygnięcie danej kwestii ${ }^{60}$.

\section{Podsumowanie}

Podsumowując, należy zauważyć, iż umowy licencyjne na korzystanie z programów komputerowych występujące $\mathrm{w}$ obrocie, podobnie jak każdy inny rodzaj umów, nie są wolne od postanowień, które mogą okazać się abuzywne. Oczywiście występują w tych umowach zarówno postanowienia, które można uznać za neutralne dla konsumenta, jak na przykład ograniczające możliwość sporządzenia kopii zapasowej do celu zastąpienia legalnie posiadanego egzemplarza, lecz z drugiej strony można w nich spotkać postanowienia, które z samej swej istoty wydają się być nieuczciwe, jak na przykład twarde klauzule CPU. Należy zaznaczyć, że ze względu na specyfikę tychże umów - fakt, iż niepodzielnie są związane ze sprzętem komputerowym, a często z Internetem, klauzule w nich spotykane nie występują $\mathrm{w}$ innych umowach licencyjnych. Wobec tego obok postanowień dotyczących dla przykładu odpowiedzialności czy jurysdykcji, jest w nich wiele postanowień charakterystycznych wyłącznie dla tych umów, a które mogą się okazać krzywdzące dla konsumenta. Dokonując zarówno kontroli incydentalnej, jak i abstrakcyjnej, powołane do tego organy powinny badać klauzule, którym zarzuca się abuzywność, mając na względzie szczególny charakter przedmiotowych umów. Należy także postulować, aby przy dokonywaniu kontroli przedmiotowych klauzul korzystać z dorobku orzecznictwa europejskiego, dotyczącego programów komputerowych, które może okazać się pomocne przy roz-

${ }^{60}$ M. Skory, Klauzule abuzywne w polskim prawie ochrony konsumenta, Zakamycze 2005, s. 277-278; 
wiązywaniu wielu wątpliwych kwestii dotyczących postanowień w umowach licencyjnych na korzystanie w programów komputerowych.

Jak wyżej opisano, szczególnie niekorzystne dla konsumentów mogą się okazać klauzule wiążące dany program z określonym sprzętem komputerowym, zakazujące przenoszenia licencji oraz zbierania danych. Czasami jednakże cechą abuzywności będą także obciążone klauzule występujące $\mathrm{w}$ większości umów, jeżeli nie $\mathrm{w}$ prawie wszystkich, a dotyczące sposobu zawierania umowy lub sporządzania kopii zapasowej.

Warto także zauważyć, iż wymienione niedozwolone klauzule mogą naruszać prawa i interesy będące przedmiotem zainteresowania czy ochrony różnych dziedzin prawa - nie tylko prawa cywilnego, np. w zakresie ograniczania swobody kontraktowania, ale także dla przykładu ochrony danych osobowych.

Wydaje się, iż ze względu na coraz szersze wykorzystywanie różnorakich programów komputerowych w życiu codziennym, także przez konsumentów, umowy te winny stać się przedmiotem zainteresowania instytucji stojących na straży praw konsumentów, a w konsekwencji być poddawane kontroli abstrakcyjnej. Należy bowiem pamiętać, iż pomimo faktu, że problematyka ta dotyka prawa autorskiego, roztaczającego szczególnego rodzaju ochronę nad uprawnionymi, to jeżeli kontrahentem jest konsument, to z założenia ma on słabszą pozycję i należna mu jest odpowiednia ochrona.

Koniecznym jest, aby tego typu umowy były przejrzyste, zrozumiałe dla konsumentów, zaś instrumenty ochrony praw podmiotów uprawnionych z tytułu przysługujących im praw autorskich powinny być adekwatne do rzeczywistego zagrożenia i nie być przyczyną rażącego naruszania praw konsumentów.

Słowa kluczowe: abuzywne, klauzule, program, komputerowy, licencja

\section{Bibliografia}

Barta J. (red.) System Prawa Prywatnego, t. 13, Warszawa 2007.

Barta J. (red.) System Prawa Prywatnego, t. 13, Warszawa 2008.

Barta J., Markiewicz R. (red.), Prawo autorskie i prawa pokrewne. Komentarz, Warszawa 2011.

Barta J., Markiewicz R., Prawo autorskie, Warszawa 2010. 
Byrska M., Program komputerowy w nowym prawie autorskim, „Państwo i Prawo" 1994, nr 11.

Czajkowska-Dąbrowska M., Licencja nie przenosi prawa autorskiego, „Przegląd Prawa Handlowego" 1995, nr 7.

Giesen B., Umowa licencyjna w prawie autorskim. Struktura i charakter prawny, Warszawa 2013.

Grzybczyk K., Prawo właścize dla autorskoprawnej umowy licencyjnej, Warszawa 2010.

J. Barta, R. Markiewicz (red.), Ustawa o prawie autorskim i prawach pokrewnych. Komentarz, LEX 2011, wersja elektroniczna, https://sip.lex.pl/\#/komentarz/ 587283695/109103? tocHit $=1 \& \mathrm{~cm}=$ REST.

Kot D., Elektroniczny obrót utworem w świetle prawa autorskiego, „Prace Instytutu Własności Intelektualnej Uniwersytetu Jagiellońskiego" 2006, z. 94.

Krochmal-Węgrzyn A., Umowa licencyjna a Internet, „Przegląd Prawa Handlowego" 2004, nr 6.

Łętowska E. (red.), System Prawa Prywatnego, Prawo zobowiazań - część ogólna, t. 5, Warszawa 2006.

Łętowska E., Europejskie prawo umów konsumenckich, Warszawa 2004.

Łętowska E., Prawo umów konsumenckich, Warszawa 2002.

Marcinkowska J., Dozwolony użytek w prawie autorskim. Podstawowe zagadnienia, „Zeszyty Naukowe Uniwersytetu Jagiellońskiego” 2004, z. 2.

Opinia rzecznika generalnego Yves'a Bota przedstawiona w dniu 24 kwietnia 2012 r., pkt 59,,http://curia.europa.eu/juris/document/document.jsf?text= \&docid $=121981 \&$ pageIndex $=0 \&$ doclang $=$ PL\&mode $=1$ st\&dir $=\& o c c=$ first\& part $=1 \&$ cid $=489176$

Pecyna M., Kontrola wzorców umownych poza obrotem konsumenckim, Zakamycze 2003.

Podrecki P. (red.), Prawo Internetu, Warszawa 2007.

Sikorski R., Licencje na korzystanie z elektronicznych baz danych, Warszawa 2006.

Skory M., Klauzule abuzywne w polskim prawie ochrony konsumenta, Zakamycze 2005.

Suchorzewska A., Ochrona prawna systemów informatycznych wobec zagrożeń cyberterroryzmem, Warszawa 2010

Ślęzak P., Umowy w zakresie wspótczesnych sztuk wizualnych, LEX 2012, wersja elektroniczna: https://sip.lex.pl/\#/monografia/369245766/80?tocHit=1

Ślęzak P., Umowy w zakresie współczesnych sztuk wizualnych, Warszawa 2012

Umowa licencyjna użytkownika końcowego firmy Kaspersky LAB, http:// www.kaspersky.pl/download/licencje/eula_kaspersky_internet_security_2013.pdf;

Wasilewski P., Umowy licencyjne open content jako przykład umów web-wrap, „CBKE Biuletyn” 2007, nr 3. 


\author{
“THE MOST COMMON ABUSIVE CLAUSES \\ IN THE LICENSE AGREEMENTS \\ FOR THE USE OF COMPUTER PROGRAMS"
}

\title{
$\mathrm{S} \mathbf{u} \mathbf{m} \mathbf{m}$ a r y
}

The article entitled "The most common abusive clauses in the license agreements for the use of computer programs" deals with the problem of abusive clauses which are most typical and frequent in contracts, concluded for the use of computer programs. In the beginning, the article describes a notion of computer program. Secondly, it answers the question what a license agreement is. Then, the article explains what the abusive clauses are and how a consumer should be protected from them. Finally, the article points the most characteristic, as well the most common abusive clauses in the license agreements for the use of computer programs. Firstly, the clauses connected with the method of concluding license agreements are described. Then, the article talks over the clauses concerning a spare copy and gathering of data. Following are clauses called CPU (Central Processing Unit), which bind a program with a specific computer. In the end, the article describes the clauses which can make impossible the transfer of a license and jurisdiction clauses.

Key words: abusive, clauses, computer, program, license

\section{БОЯЕЕ ЧАСТО РАСПРОСТРАНЁННЫЕ ЗЯОУПОТРЕБЯЯЮЩИЕ ПОЯОЖЕНИЯ В ЯИЦЕНЗИОННЫХ ДОГОВОРАХ ПО ИСПОЯЬЗОВАНИЮ КОМПЬЮТЕРНЫХ ПРОГРАММ}

$$
\text { P е } 3 \text { ю м е }
$$

Статья под названием „Более часто распространённые злоупотребляющие положения в лицензионных договорах по исподьзованию компьютерных программ" касается вопросов наиболее характерных и распространённых злоупотребляющих положений в договорах по использованию компьютерных программ. Для начала, статья описывает понятие компьютерной программы. Во-вторых, отвечает на вопрос, что являет собой дицензионный договор. Далее, статья описывает, что является злоупотребляющим положением и как потребитель должен быть защищен перед этим. В конце прописано более типичные и, одновременно, более частые злоупотребляющие положения в лицензионных договорах по использованию компьютерных программ. Во первых, описанные положения связаны с заключением таких договоров. Далее, в статье указано пояожения, что касаются резервной копии и сбора данных. Следующие, проанализированы были положения центрального процессорного устройства, которые связывают программу с конкретным 
компьютером. На конец статьи описаны положения, которые могут не допустить передачу лицензии и положения о юрисдикции.

Ключивые слова: злоупотребляющие, положения, программ, компьютерный, лицензия 